\title{
Environment and health with respect to a poverty- related disease: the epidemiology of trachoma in Spain, 1925-1941*
}

\section{Ambiente e saúde em doença relacionada a pobreza: a epidemiologia do tracoma na Espanha, 1925-1941 \\ Josep Bernabeu-Mestre \\ Professor do Department of Community Nursing, Preventive Medicine and Public Health and History of Science/University of Alicante. Campus de San Vicente del Raspeig, Ap. 99 \\ E-03080 - Alicante - Espanha \\ josep.bernabeu@ua.es}

\section{María Eugenia Galiana-Sánchez}

Professora do Department of Community Nursing, Preventive Medicine and Public Health and History of Science/University of Alicante.

Campus de San Vicente del Raspeig, Ap. 99 E-03080 - Alicante - Espanha

galiana@ua.es

\section{Angela Cremades Monerris}

Doutoranda do Public Health Programe/University of Alicante. Campus de San Vicente del Raspeig, Ap. 99 E-03080 - Alicante - Espanha

angiscm@hotmail.com
BERNABEU-MESTRE, Josep; GALIANASÁNCHEZ, María Eugenia; CREMADES MONERRIS, Angela. Environment and health with respect to a poverty-related disease: the epidemiology of trachoma in Spain, 1925-1941. História, Ciências, Saúde - Manguinhos, Rio de Janeiro, v.20, n.4, out.-dez. 2013, p.1605-1619.

\section{Abstract}

Trachoma currently represents one of the three main causes of 'avoidable' blindness and reaches intolerable dimensions in many developing countries. It was endemic in many regions of eastern Spain until well into the twentieth century. The aim of this paper is to analyze the epidemiological development of this disease in contemporary Spain; to examine its determining factors, particularly environmental and sanitary/health factors, and, finally, to study the health care, environmental and socio-economic measures that led to its control and eradication. We believe that the historical approach not only highlights the role of environmental factors in the development of trachoma, but may also aid in understanding the current epidemiology of trachoma.

Keywords: trachoma; environmental health; Spain (1925-1941); public health.

\section{Resumo}

O tracoma representa hoje uma das três principais causas de cegueira 'evitável' e tem alcance inaceitável em muitos países em desenvolvimento. Era doença endêmica em muitas regiões da Espanha oriental século $X X$ adentro. O objetivo do presente artigo é analisar o desenvolvimento epidemiológico da doença na Espanha contemporânea; examinar seus fatores determinantes, especialmente os ambientais e sanitários, e, finalmente, estudar as medidas de assistência médica, socioeconômicas e ambientais que levaram a seu controle e erradicação. Acredita-se que a abordagem histórica revela a importância dos fatores ambientais no desenvolvimento do tracoma e ajuda a compreender o perfil epidemiológico atual da doença.

Palavras-chave: tracoma; cegueira; saúde ambiental; Espanha (1925-1941); saúde pública.
Recebido para publicação em junho de 2011.
Aprovado para publicação em março de 2012.

http://dx.doi.org/10.1590/S0104-597020130005000010 
$\mathrm{T}$ rachoma, an eye disease caused by the Chlamydia trachomatis bacterium, is currently one of the three major causes of "preventable" blindness. ${ }^{1}$ The disease is endemic in 49 countries, principally in Africa, but also in Asia and the western Pacific. It is estimated that over six million people are blind, visually handicapped or at immediate risk of blindness as a result of the disease. A further 146 million cases of active trachoma require treatment and 500 million more people are at risk of contracting the infection. Regions in which trachoma is most frequently seen are characterized by their poverty and lack of basic necessities such as housing, health services, water and sanitation. In 1997, the World Health Organization (WHO) instituted the GET 2020 plan with the aim of eliminating blinding trachoma worldwide; more recently the SAFE strategy has been developed (surgical correction, administration of antibiotics, hygiene, including facial cleanliness, and environmental improvements) (Mariotti, Prüss, 2000; Konyama, 2004-2005; Taylor, 2008; Wright, Turner, Taylor, 2008).

This paper forms part of a field of research aimed at analyzing the historical problem of trachoma through an analysis of the epidemiological evolution of the endemic which used to affect large parts of Spain until the 1960s. In previous studies, we addressed the conceptual and methodological assumptions underlying the social struggle against trachoma in the 1920s and 1930s and we analyzed the prevalence of trachoma in rural areas (Galiana-Sánchez, Cremades, Bernabeu-Mestre, 2010). We also studied the factors explaining the prevalence of trachoma in infants, paying particular attention to family, school and community intervention strategies (Bernabeu-Mestre, Galiana-Sánchez, 2011). In this paper, we have focused on the epidemiological problem presented by trachoma in Spain between the two World Wars and, more specifically, on an analysis of its environmental determinants.

The principal factors underlying this significant public health problem are addressed. In particular, factors of an environmental nature (such as, inter alia, those related to the hydrologic cycle, climate, soil or manufacturing activities), of a hygiene-health nature (including living conditions and personal and public hygiene) and of a demographic nature (such as those caused by migratory movement) are treated. In addition, the health, environmental and socioeconomic measures that enabled the disease to be controlled and eradicated are also studied.

As well as highlighting the role played by environmental factors in the development of a health problem like trachoma, we believe that a historical reflection on these characteristics can aid in the understanding of many of the determinants that continue to be related to this disease. Its persistence will also provide further cause for debate, as will the measures that must be taken in order to achieve its eradication.

In this study, we have consulted information brochures, monographs, articles and congress presentations published by the General Health Directory (Dirección General de Sanidad) and by the staff of the National Health Board (Cuerpo Nacional de Sanidad), responsible for the fight against trachoma. We also drew upon papers by various ophthalmologists, especially those who have dealt with trachoma as a public health problem.

\section{The trachoma endemic in Spain in the first half of the twentieth century}

During the early decades of the twentieth century, trachoma was endemic in many parts of Europe. The data collected from the papers presented at the thirteenth International 
Ophthalmological Congress, which took place in Amsterdam in 1929, highlighted the incidence of the disease in Mediterranean countries and the recrudescence of the disease after the First World War as a result of the deterioration in living conditions experienced by large parts of the population (Arjona, Alonso, 1941, p.16-19). Spain was one of the countries most deeply affected, with an endemic trachoma zone which extended the length of the Mediterranean coast from the province of Gerona as far as Alicante, Murcia and Almería, with significant outbreaks in the provinces of Granada, Málaga, Cádiz, Huelva and Sevilla (Arjona, Alonso, 1941, p.13).

Although the disease was declared notifiable in Spain from 1919 onwards (by Royal Decree dated January 10) (Arjona, Alonso, 1941, p.136-137), the first Spanish statistics on trachoma date back to 1925 (Ortiz, Luengo, 1925, p.398-399). ${ }^{2}$ They cited the existence of more than 45,000 trachoma sufferers (which would be equivalent to a rate of two sufferers per thousand inhabitants) at a time when under-reporting was a problem. The incidence of the disease in the provinces of Murcia, Almería, Valencia, Castellón and Alicante (see Map 1) was highlighted.

Despite the difficulties entailed in obtaining reliable statistics on the number of trachoma sufferers and the irregular publication of this data, in 1933 the Health Department provided data on the 1932 anti-trachoma campaign, which showed that there were more than 50,000 people suffering from the disease, although it was suspected that there could actually have been as many as 100,000 (an infection rate varying from 2.12 to 4.24 per thousand

Map 1 - Rates (per thousand inhabitants) of Trachoma in Spain (by province), 1925

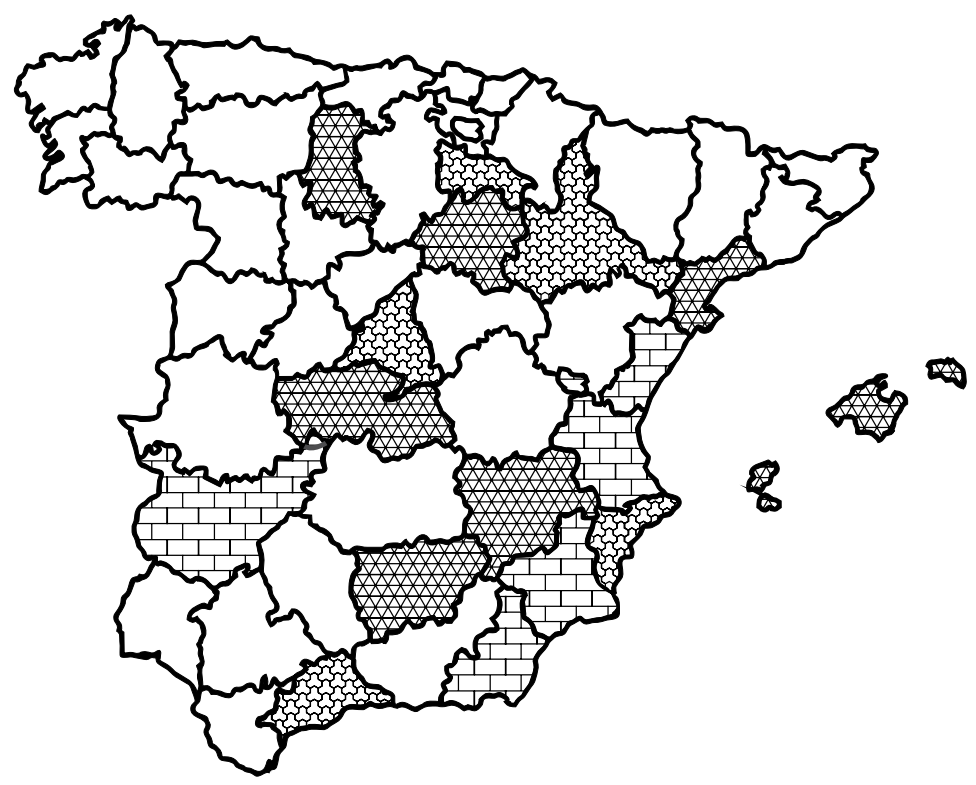

Rates per thousand inhabitants

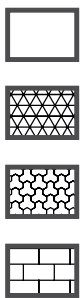

$0.01-0.83$

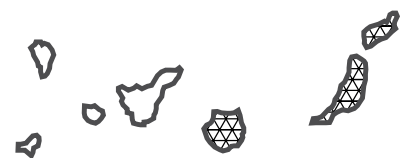

Source: Arjona, Alonso (1941, p.15), data drawn from the Marquez and Soria study 
inhabitants) (Arjona, Alonso, p.1941, p.14). In the 1932 campaign alone, 32,041 new cases were diagnosed, with the provinces of Murcia, Almería, Granada, Alicante, Valencia and Castellón most affected (Álvarez Torres, 1934, p.259) (see Table 1).

In the 1932 campaign, along with cases dealt with in dispensaries, 733 examinations were carried out in schools, factories, workshops, socio-economically depressed areas and asylums in the provinces of Alicante, Almería, Castellón, Granada, Huelva, Málaga, Murcia and Valencia, areas which - based on trachoma endemic data - were the most affected. In total, 41,865 individuals were examined, of whom 5,838 were diagnosed with trachoma, i.e. 14\% (Álvarez Torres, 1934, p.259).

Although we do not have data available that would enable us to determine the impact of this health campaign, in terms of reduction and control of the number of cases, the sources consulted do provide information about the actions implemented. Three years later, in 1935, anti-trachoma services dealt with 31,649 trachoma sufferers, of whom 20\% were registered as incipient $(6,329)$. There were more women $(52.6 \%)$ than men and, by age group, infants were the most frequently affected (39.7\%), followed by adults (32.6\%) and adolescents (28\%) (Arjona, Alonso, 1941, p.14).

After the civil war, and in particular during the early post-war years, deteriorating living conditions and population movement provided ideal conditions for a fresh outbreak of endemic trachoma. In the 1960s, the disease continued to pose a public health problem and remained endemic in twelve Spanish provinces, although the number of cases was considerably reduced and its incidence was limited to risk groups and the marginal population. The statistics referred to 21,543 cases, of which $57.8 \%$ were active and the remainder was scarred by the disease (Gimeno de Sande, 1965, p.109-110).

The trachoma health campaigns carried out in Spain in the 1920s and 1930s should be seen in the context of the momentum gained by public health, and in particular by the community health initiatives implemented within the framework of the cooperation agreement with the Rockefeller Foundation and those promoted by the Republican health administration from 1931 onwards (Rodríguez Ocaña, Martínez Navarro, 2008, p.66-84;

Table 1 - New cases of trachoma diagnosed in anti-trachoma dispensaries in Spain during the 1932 campaign

\begin{tabular}{|l|c|c|}
\hline Province & $\begin{array}{l}\text { New cases } \\
\text { of trachoma } \\
\text { (diagnosed in clinics) }\end{array}$ & $\begin{array}{l}\text { Percent of new } \\
\text { cases, in Spain } \\
\text { (cumulative figures } \\
\text { in parentheses) }\end{array}$ \\
\hline Almería & 6,866 & 26.28 \\
\hline Murcia & 5,596 & $21.35(47.63)$ \\
\hline Granada & 3,569 & $13.62(61.25)$ \\
\hline Alicante & 2,939 & $11.21(75.46)$ \\
\hline Valencia & 2,118 & $8.08(83.54)$ \\
\hline Castellón & 1,419 & $5.4(88.94)$ \\
\hline
\end{tabular}

Source: Álvarez Torres (1934, p.259) 
Barona, Bernabeu, 2008, p.89-142, 231-262). In addition to the fight against trachoma, in the first decades of the twentieth century various health campaigns were begun to attempt to address some of the health problems which were particularly prevalent among the Spanish population, such as tuberculosis, malaria, hookworm and leprosy (Martínez Antonio, Molero Mesa, 2002; Rodríguez Ocaña et al., 2003 Rodríguez Ocaña, Molero, 2005; Rodríguez Ocaña, Menéndez, 2006; Martínez Navarro, 2009). Attention was also paid to the issue of mother-child health (Rodríguez Ocaña, 2001; Pediguero, 2004; Barona 2006) and to the health problems associated with rural living (Barona, Bernabeu, Perdiguero, 2005; Galiana, Bernabeu, 2006, Barona 2009; Rodríguez Ocaña, 2010).

\section{Poverty and environment: the epidemiological determinants of trachoma}

In 1936, Pedro Rabadán, who led the fight against trachoma in the province of Alicante, one of the areas of Mediterranean Spain most severely affected by the disease, described it as "the disease of poverty" (Rabadán, 1936, p.416). In using this expression, he was attempting to collect together the set of determinants that lay behind the problem of trachoma and that were clearly grouped around a single element: the impoverished living conditions which affected a large part of the Spanish population in the early decades of the $20^{\text {th }}$ century, particularly in rural areas (Galiana-Sánchez, Bernabeu-Mestre, 2006, p.141-143).

In the Spanish sources which we have reviewed, three major groups of determinants in the epidemiological problem of trachoma have been established: those related to human biology, factors relating to environmental conditions, and a third group of factors connected with socio-economics, demographics and hygiene. As more than one study has indicated, penury and poverty were important factors in the causal relationship, whilst the remaining factors played a "contributory" role (Socías, 1940, p.321-328).

The first group of factors referred to a set of circumstances which influenced the general state of the individual, from infections to nutritional problems, ${ }^{3}$ which the authors believed could encourage trachomatous contagion.

The second group of determinants contained the environmental factors, such as climate, geological composition of the soil and orography, as well as elements linked to the water cycle.

Epidemiological studies how trachoma affected the Spanish population highlighted the subtropical climate of the affected areas, characterized by temperatures over $15^{\circ} \mathrm{C}$ in the winter and up to $50^{\circ} \mathrm{C}$ in the summer, conditions which encourage microbe proliferation, a key to the development of the disease, as we have also had occasion to note. Furthermore, the diaphaneity of the environment frequently added to the effects of heat on the eyeball, imbuing solar radiation with maximum luminous intensity. Similarly, a certain seasonal periodicity was noted, meaning that the greatest number of cases occurred, as was to be expected, in the hottest months, from August to October.

By carrying along large quantities of suspended matter, the intense winds present in some of these regions also tended to cause conjunctival erosion through mechanical action or toxicity through chemical action.

The effect of all these conditions was interpreted thus: the heat generated increased conjunctival secretions, altering the physical-chemical defense of the eye and encouraging 
the proliferation of germs. If more or less septic particulates, or particulates which could cause erosion, were deposited on the mucous membrane in these conditions, the ideal conditions for trachoma were created.

Another environmental element that appeared to increase trachoma contagion was settlement in areas in which the geological composition of the soil was rich in limestone and salt, which accentuated the dryness of the environment. ${ }^{4}$

However, it was undoubtedly problems relating to the water cycle - both scarcity and contamination - which were highlighted more than any other by Spanish health experts, since they were directly related to lack of hygiene and increased the risk factor for the development of infectious diseases such as trachoma.

The scarcity of rain in the most affected areas led to poverty, and people restricted its use as much as possible. The little rain that did fall was stored in tanks under dubious sanitary conditions, since they were positioned close to septic tanks and stables where animals were kept. Nor was water from underground sources available, since it was at great depth and saltsaturated, rendering it unsuitable for either cultivation or personal and domestic cleaning. When the source was surface water, the situation was not much better. In areas with the highest levels of morbidity, such as those in the Vega Baja de Segura in the province of Alicante, for example, water was taken directly from the river (Rabadán, 1936, p.420). After the river had run through the main towns in the area, gathering their waste products, it was diverted to water the market gardens and for domestic use, both for drinking and for personal cleaning, its only treatment being storage in clay receptacles intended to remove the filth through the effect of sedimentation. However, the most extreme conditions were seen in families who had access to neither water storage tanks, nor the river. These people collected the water which fell on roads and fields when it rained and which was highly contaminated. In such circumstances, hygiene practices were extremely compromised. Using this contaminated water for ocular hygiene caused conjunctival irritation and repeated infections. Trachoma sufferers were unable to carry out minimal hygiene procedures, meaning that secretions accumulated in the conjunctiva and health practitioners frequently had to separate the eyelids with tweezers, leading to bleeding, which hindered recovery. Doctor Rabadán (1936, p.419) summarized the role that the scarcity of water in the province of Alicante played in the epidemiology of trachoma thus:

The absence of water creates desperation in the inhabitants of these areas; reducing the people to poverty, people for whom nature has not provided stimulation for work and who are therefore prisoners of a state of apathy in which they forget even the most basic principles of personal hygiene, thus creating the epidemiological basis for trachoma.

The final category of determinants includes living conditions, people's daily habits, work and productive activity and population movement, as well as overcrowding and population concentration.

Living conditions in Spain during the period that we are discussing, especially in rural areas, were extremely poor (Galiana-Sánchez, Bernabeu-Mestre, 2006, p.141-143). People lived in unsanitary conditions, even families that were better off. Standards of personal cleanliness were deplorable and swarming flies were a constant feature of daily life. The poorest homes were actual caves in which all the members of a family, and even 
their domestic animals, lived together in a single room. Along with these unfavorable circumstances, some writers mentioned what they called "unforgivable slovenliness" (Arjona, Alonso, p.1941, p.132), highlighting the contribution that poor personal habits made to the occurrence of the disease. Behavior such as rubbing the eyes, removing foreign bodies with the hands or the tongue, or washing out the eyes with "miracle waters" were seen by health professionals as signs of ignorance and laxness which contributed to the problem.

As far as work is concerned, the studies reviewed (Rabadán, 1936, p.421; Arjona, Alonso, 1941, p.148-149) observed that working activities that caused corneal and conjunctival irritation were responsible for providing entry routes for the infection, as a result of their damaging action. People who worked in the growing of hemp or rice, the esparto grass industry, sea fishing (especially for varieties of mahi-mahi and scorpion fish), tanning or pottery had an increased risk of contracting the disease. The statement on the esparto grass industry included in the annual report of the Lorca Anti-Trachoma dispensary in the province of Murcia is particularly significant (Álvarez Torres, 1934, p.257):

In esparto grass factories, adding to the lack of hygiene and the poverty of the workers is the enormous amount of dust, which is so great, especially in the departments where crushed esparto is handled, that it renders the air practically unbreathable, the faces of all those who work there being completely covered in it. These departments are staffed principally by men, the women handling the uncrushed esparto more, which may explain why the percentage of female sufferers is lower than that of males.

Similarly, migratory phenomena contributed to the spread and worsening of the trachoma endemic. In Barcelona and many Catalan towns, it was of particular significance. As Vila i Coro (1933, p.11-12) acknowledged in his monograph on trachoma, large numbers of people came from the poorest Spanish regions, such as Murcia, Almería, Alicante and Castellón, where trachoma was endemic, in search of the work opportunities which Catalan industry offered. There was no cordon sanitaire to stop the invasion of trachoma, and the overcrowding and lack of hygiene in the accommodations where such groups lived aggravated the situation, turning Barcelona into one of the cities with the highest levels of trachoma in Spain. In 1927 it was calculated that the rate of trachoma infection in the city was 15 trachoma sufferers per thousand inhabitants, whereas in 1910 it had been barely one per thousand.

Unlike other countries that had strict regulations to prevent trachoma sufferers from entering the country or controlled their movement, Spanish legislation did not provide for measures of this type (Arjona, Alonso, 1941, p.145-151). This explains the public health problems experienced in some areas of French Algeria by the groups of Spanish trachoma sufferers who temporarily emigrated there ${ }^{5}$ from the provinces of Alicante and Almería, with no control exercised by the Spanish authorities, or the paper which one of those responsible for the anti-trachoma fight published (Álvarez Torres, 1934, p.258) on this lack of control and its consequences:

In Spain there are no regulations to protect us from the importation of trachoma by foreigners, above all Moroccans, Hungarians, gypsies and individuals coming from Portugal and the south of France. Even within our own country, we have sufferers who travel (from trachoma zones to previously unaffected areas) in search of work, leading to 
real epidemics of granular ophthalmia, a phenomenon which we observe annually in the provinces of Catalonia, as a result of immigration from Almería, Murcia and Castellón.

Finally, the crowding together of people in institutions such as asylums, schools, boarding schools or military barracks also encouraged the spread of the disease.

As an example of the convergence of some of the determining factors that we have just described, we would cite the example of the Murcian town of Águilas. The endemic problem of trachoma there was increased by the environmental deterioration brought about by the introduction of iron ore trading in its port, which led to the opening in 1925 of what was considered to be the first anti-trachoma dispensary in Spain. ${ }^{6}$ The spreading via air of large quantities of iron particulates in the dust that the wind whipped up in the area worsened eye infections caused by the lack of hygiene and inadequate living conditions of the majority of the population and the esparto grass industry. As one port health clinic reports (Borja Martín, 1924, p.75) stated:

over twenty years ago, the company that built this port set aside the extensive leveled area of land gained from the sea, situated between the port and the point where the town's main roads end, for permanent warehouses for the storage of iron. This zone, which had previously provided the largest 'green space' in the area, was also the inhabitants' favorite place for recreation and relaxation. After the company developed the area, many people protested and complained, asking that these iron storage warehouses be moved to another site in the port, away from the residents, who were frequently assaulted by strong winds blowing dust whipped up from the iron, but they were ignored by the administration.

\section{Prophylaxis and education in the fight against trachoma: the role of dispensaries and rural health centers}

Despite the public health problem posed by trachoma in the early decades of the twentieth century in Spain, the first initiatives in the systematic fight against the disease were seen in the health reforms brought in during the Primo de Rivera dictatorship (Huertas, 2000), through the creation in 1927 of a National Anti-Trachoma Service, with provincial management boards as consultative bodies in some provinces. ${ }^{7}$

As mentioned in the introduction, it was in the context of the health reforms instigated in the 1930s by the Republican health administration (Rodríguez Ocaña, Martínez Navarro, 2008, p.66-84; Barona, Bernabeu, 2008, p.89-142) that the greatest efforts were made to address the problem of trachoma. The dispensaries became the hubs of anti-trachoma activity. ${ }^{8}$ The distribution of anti-trachoma dispensaries and the specialized services which were introduced, especially after the arrival of the Second Republic, reflect the geographical extent of the endemic and its intensity. In 1934, in addition to the National Ophthalmological Institute, the fight against trachoma had a total of 76 dispensaries, ten specialized services and two ophthalmology clinics, distributed as shown in Map 2 (Álvarez Torres, 1934, p.259; Arjona, Alonso, p.1941, p.138-145):

Specialist clinics were created to supplement the tertiary-type trachoma dispensaries operating in some of the provincial health institutes (Arjona, Alonso, 1941, p.139-140). In 
addition to the public health functions that their ophthalmology units carried out, ${ }^{9}$ this type of service assumed responsibility for preparing health statistics, co-ordinating primary dispensaries, carrying out inspection and supervision tasks relating to preventive and therapeutic activities, checking for compliance with the notification requirements of the disease and the health follow-up of all those infected, with the aim of preventing their migration, thus stopping one of the epidemiological factors which most contributed to its spread.

For their part, the primary dispensaries or local services, which were located in designated towns in the provinces most affected by the endemic, offered free medical appointments and applied health and epidemiological control measures, such as school inspections and workplace visits (Arjona, Alonso, 1941, p.138-139). ${ }^{10}$ Their principal activity was, however, individual and family prophylaxis.

The presence of specialist staff, skilled in the fight against trachoma, was important, but the preparation of all health professionals through the specialization courses organized in many provincial health institutes was also stressed. Trachoma was, as we have seen, a problem that affected the rural world most acutely, which is why the role of municipal health inspectors in its prophylaxis was so vital.

Along with primary care, the other factor that proved to be key for trachoma prophylaxis was the work carried out by health inspectors. As one of the studies which we reviewed put it (Arjona, Alonso, 1941, p.135):

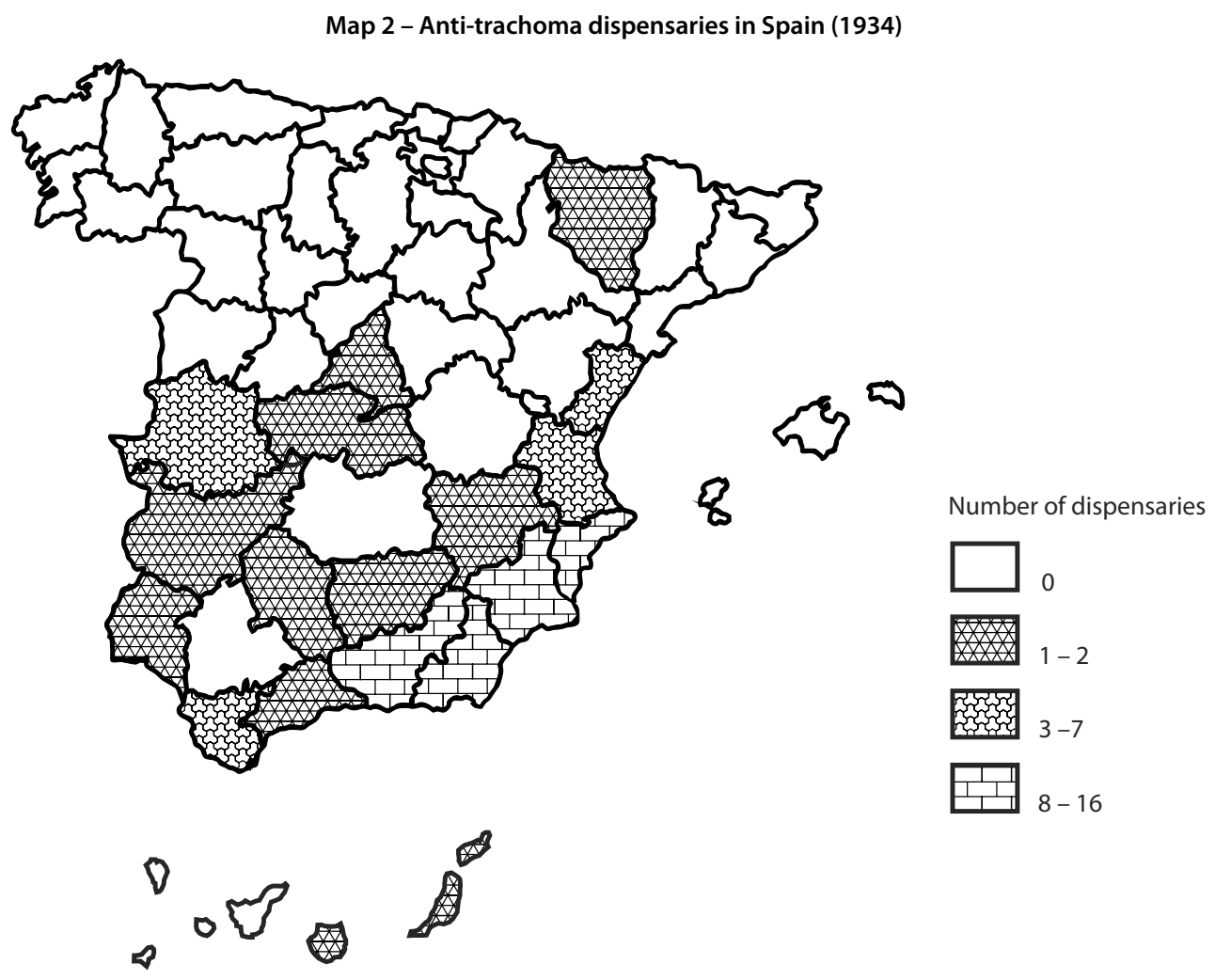

Source: Alvárez Torres (1934, p.259); Arjona, Alonso (1941, p.138-145) 
In the fight against trachoma, community health workers can play a significant role both in the identification of cases, since if trachoma sufferers do not seek assistance, they have to be found, and through the health education that they provide. It is to be hoped that state and charitable institutions will multiply the numbers of these selfless professionals, since it must not be forgotten that the first step towards perfect health is perfect hygiene in personal and domestic habits.

The main obstacles that health professionals reported when attempting to control trachoma was "ignorance, slovenliness and even certain superstitious prejudices," meaning that trachoma sufferers did not go to clinics, leading to the need for advance health information campaigns and even proselytizing activities (Álvarez Torres, 1934, p.253). The anti-trachoma dispensaries, especially primary care and rural health centers, played a notable role in this type of activity.

Trachoma prophylaxis started with the medical examination of pregnant women ${ }^{11}$ who had been referred by ophthalmologists; it continued with the work carried out by community health workers, who sent other family members suffering from granular ophthalmia to the dispensaries, especially women, who had the most contact with newborns; and it ended with monitoring of the child's health in terms of food, hygiene and eye care. Ongoing health information, regular home visits, well-managed breast-feeding and appropriate treatment of diseases which could cause constitutional problems could, in the opinion of Spanish health practitioners, prevent "the lack of cleanliness, promiscuity, lymphatism, avitaminosis, conjunctivitis neonatorum and many other factors which are so important in the etiology of infection" (Álvarez Torres, 1934, p.255).

As we have outlined above, Spanish health professionals considered that "infectious diseases in general, hereditary defects or inadequate nutrition which produce physical decline" predisposed people to trachoma and aggravated the disease, thus leading Arjona and Alonso (1941, p.147) to propose:

elevating the lifestyle of the lower classes and fighting against everything which has been proved to produce organic poverty (alcoholism, tuberculosis, syphilis, overwork) ... above all, breast-feeding will be closely observed and particularly bottle-feeding, where it must be ensured that the child is taking in sufficient levels of vitamins $\mathrm{A}$ and $\mathrm{C}$, as these vitamins powerfully stimulate lysozyme concentration. This factor has the greatest effect on local receptivity, which is so important in the early years of life. From here also arises the need to fight against scrofula through vitamin and antitubercular therapy.

The school environment was another fundamental factor in the fight against trachoma. As has already been seen, one of the functions of the local services were school inspections and the treatment and monitoring of children with trachoma; however, when the School Medical Inspectorate was created in 1933 (by Decree on April 17), it assumed responsibility, along with its other functions, for treating all cases of trachoma and other contagious eye diseases, for the investigation and treatment of family members of affected children, and for providing them with the necessary understanding of "hygiene and health". Spanish health professionals continually reported that for these interventions to be successful, trachoma treatment had to be obligatory, while also indicating that "instead of keeping trachoma sufferers away from schools, based on misunderstood isolation,"12 they should be treated in annexed 
dispensaries, thus leading to the creation of special schools for trachoma sufferers, a project which had already been developed in Spain, but had not yet been put into practice (Álvarez Torres, 1934, p.256).

In addition to schools, another environment that required prophylactic initiatives was the workplace. In the section in which we analyzed epidemiological determinants, we noted the types of activity that increased the risk factor for trachoma contagion. Factory and workshop inspections appear to have been regular, at least from 1932 onwards (Álvarez Torres, 1934, p.259).

Trachoma sufferers were giving only a temporary exemption from military service, as the Spanish health authorities considering the disease to be temporary. Draftees were required to undergo treatment and, once cured, were drafted (Álvarez Torres, 1934, p.258; Arjona, Alonso, 1941, p.143).

Another of the demands of Spanish health professionals was the creation of asylums to treat trachoma sufferers with no personal means of support. This was considered to be indispensable for social, ethical and charitable reasons, as well as, above all, for health motives: "trachoma being a disease which is almost always accompanied by abandon, promiscuity and poverty ... beggars with granular ophthalmia and those blinded by trachoma, far from wandering the streets, should be rounded up and isolated in special centers where they can receive appropriate treatment, while at the same time being removed from contact with the public, thus avoiding further contagion" (Álvarez Torres, 1934, p.259).

In spite of all the initiatives and measures which we have outlined, many voices were still raised in criticism of the inadequacy of the measures adopted to reduce the incidence of a disease that continued to be endemic in many regions of Spain. According to Arjona and Alonso (1941, p.140-141), "discontinuing mobile teams in favor of specialized centers was a mistake".

\section{Final considerations}

In the early decades of the twentieth century, Spain was one of the European countries most affected by trachoma, with an endemic zone that covered the entire Mediterranean coastal area. Nationally, statistics showed an infection rate that varied from 2.12 to 4.24 per thousand inhabitants. There were more women (52.6\%) than men and, by age group, infants were the most frequently affected (39.7\%), followed by adults (32.6\%) and adolescents (28\%).

According to the Spanish health professionals who were responsible for dealing with the trachoma problem in Spain in the early decades of the twentieth century, the main problem was rooted in a lack of personal and public hygiene, which was a consequence of a number of factors, including some of an environmental nature. These included the subtropical climate which characterized the majority of endemic areas, along with the diaphaneity of the environment, the winds and the dryness, as well as problems associated with the hydrological cycle, notably water scarcity, and certain manufacturing activities.

Control of trachoma was achieved through prophylaxis and the preventative, educational and inspection activities undertaken in dispensaries and rural health centers. Faced with the obstacle posed by the lack of public collaboration, the work of community health workers 
who visited families and other professionals such as municipal health inspectors was pivotal, through actively searching for trachoma sufferers, early detection of the disease and modifying some of the risk factors which appeared to be linked to the insalubrity of homes and lack of hygiene.

The historical experience in Spain highlights the importance of prophylactic action and modification of determining factors in controlling a disease of poverty like trachoma. As the initiatives promoted by various NGOs and the WHO itself show, in order to solve the health problems posed by trachoma, which continues to affect the least developed and poorest parts of the planet, it is not enough to simply take action on the most immediate factors through therapeutic resources. Health conditions and the environmental factors that are responsible for the prevalence of the disease must also be improved through horizontal community intervention (Mariotti, Prüss, 2000; Konyama, 2004-2005; Wright, Turner, Taylor, 2008).

\section{NOTES}

* Part of this study was carried out within the framework of the coordinated research project entitled "The struggle against undernutrition in contemporary Spain and the international context (1874-1975)". HAR2009-13504-C02-01; "International Health and the Transfer of Scientific Knowledge, Europe 19001975", HAR2011-23233 Spanish Ministry of Science and Innovation and Prometeo/2009/122. Generalitat Valenciana http://www.grupogadea.org/.

${ }^{1}$ The condition starts slowly as conjunctivitis. If it remains untreated, it can lead to scarring. If the eyelids become severely irritated, the eyelashes may turn inwards and rub against the cornea, causing eye ulcers, further scarring, loss of vision and blindness.

${ }^{2}$ Interest in the trachoma endemic was particularly keen among ophthalmologists. In September 1923, the $13^{\text {th }}$ Assembly of the Hispano-American Ophthalmological Society was held in Seville. It reached agreement on various measures relating to trachoma, including the fact that, in and of itself, the condition should not provide grounds for exemption from military service and that the ophthalmological society itself should become a national trachoma consultative center where trachoma sufferers could receive treatment (López de Letona, 2006). In fact, the first statistics on trachoma came from the study carried out by two of the most reputable Spanish ophthalmologists of that era, Doctors Márquez and Soria.

${ }^{3}$ These were conditions that could not be changed or were difficult to change, and that could predispose individuals to the disease. As Arjona and Alonso noted (1941, p.71), a pre-trachomatous state existed, characterized by "respiratory infections and fevers resulting from inadequate nutrition ... peribronchial hypertrophy with adenoids ... tonsil hypertrophy or endocrinological disorders." Some authors even drew up a morphological portrait of a typical trachoma sufferer: an adenoidal type with craniofacial deformities, such as a low nasal bridge or a collapsed cranial suture. This predisposition was also believed to be relevant in relation to resistance to treatment, and six subgroups of sufferers were set out by morphological characteristics and greater or lesser therapeutic response. Previous infections, especially local infections such as conjunctivitis, but also systemic infections such as syphilis or tuberculosis, were also considered to be predisposing factors. There was a divergence of opinions on this last question, some authors believing that there was a specific pathogenic link between trachoma and tuberculosis, while others believed them to be antagonists, even going so far as to propose using granular plasma to treat tuberculosis. Heredity was also considered to be an element to be borne in mind, leading to the statement that "trachoma is not hereditary, but the defects which encourage it are" (Arjona, Alonso, 1941, p.77).

${ }^{4}$ The areas experiencing the greatest number of cases were situated on the coast, and a clear negative connection could therefore be made between the high altitudes of mountainous areas and the appearance of the condition (Vila i Coro, 1933, p.13). A greater incidence of the condition was therefore attributed to proximity to the sea, both on the issue of altitude and the idea of infection via parasitized or infected fish.

${ }^{5}$ In the region of Oran, 66\% of trachoma sufferers were of Spanish origin (Arjona, Alonso, 1941, p.19).

${ }^{6}$ It was the port's External Health Service (to be precise, the manager of the health clinic, José Estellés Salarich) that assumed responsibility for offering free treatment to trachoma sufferers (Bernabeu, 2007, p.38). 


\begin{abstract}
${ }^{7}$ These first initiatives must be seen within the context of the institutionalization process through which Spanish public health services passed in the 1920s and 1930s, and within the framework of the collaboration agreement between Spain and the Rockefeller Foundation, as well as the influence which developments in international public health were having on the development of public health in Spain (Barona, Bernabeu, 2008). Also, in 1927, the Trachoma League was created in Paris, and a few years later the League of Nations, through its Health Committee, set up The International Organization of the Fight Against Trachoma, whose first meeting was held on July 26, 1930, and which also promoted specialized scientific publications on the subject, such as the Revue Internationale du Trachome. In 1933, the fourteenth Concilium Ophtalmologicum took place in Madrid (Arjona, Alonso, 1941, p.145-151).
\end{abstract}

${ }^{8}$ Carmen Barona's study (2006) on the situation in the province of Valencia can be used as a reference on the role of anti-trachoma dispensaries and their insertion into the public health structures that were developed at a peripheral administration level in Spain during the 1920s and 1930s. For more information about sanitary campaigns against trachoma in rural Spain, see the study by Galiana, Cremades, and Bernabeu (2010).

${ }^{9}$ This type of dispensary had a group of ophthalmology specialists at its disposal. They were responsible for dealing with patients referred to their clinics and referring them on to surgical departments and hospital units.

${ }^{10}$ Many of these measures had already been considered in the Reglamento de Profilaxis del Tracoma (Trachoma Prophylaxis Regulation) of May 3, 1928, which regulated the dispensaries' functions (Arjona, Alonso, 1941, p.136-137), but were extended in later regulations, particularly following the health reforms brought into force under the Second Republic.

${ }^{11}$ The head of the Trachoma Section of the Health Department defined the evolution of trachoma in the endemic zone of the Spanish Levante thus (Álvarez Torres, 1934, p.255): "In our area of the Levante, where trachoma is endemic, its clinical evolution could be said to start in early childhood - latent infection - from a trachoma hotspot or a contagion-producing medium and continues its silent march without complications until the child reaches school age or adolescence, when an outbreak of 'super-infection' occurs, which may be short or long-lasting, but which is always followed by a series of outbreaks, present in adults with differing frequency ... in addition to this latent infection in childhood, we have cases of adolescent and adult contamination, which require frequent physical contact, and contagion is thus less frequent but easier, and individual prophylaxis has been shown to have more positive results ... health efforts must consequently be focused on the child, especially while still breast-feeding, and in this respect Rural Health Centers are of great importance."

${ }^{12}$ Trachoma sufferers without secretions presented little danger to others if they observed hygiene guidelines. It was better for active trachoma sufferers to remain at school, since they could thus be treated and controlled. Kept away from school, not only were they condemned to illiteracy, but they also stopped attending dispensary clinics and health services, thus becoming a source of contagion within the family and their wider circle and contributing to the spread of trachoma (Álvarez Torres, 1934, p.257).

\title{
REFERENCES
}

ÁLVAREZ TORRES, Ramón.

La lucha contra el tracoma en España. In: Nájera, Luis (Ed). Libro de Actas del Primer Congreso Nacional de Sanidad. Madrid: Dirección General de Sanidad. p.253-262. 1934.

\section{ARJONA TRAPOTE, Juan; ALONSO DE MEDINA Y BONO, Francisco. \\ El tracoma. Madrid: Aldecoa. 1941.}

BARONA VILAR, Carmen.

Las políticas de la salud: la sanidad valenciana entre 1855 y 1936. València: Universitat de València. 2006.

BARONA VILAR, Josep Lluis. La sanitat rural, una qüestió d'estat. In: GuillemLlobat, Ximo; García Frasquet, Gabriel (Ed.). Salut, alimentació i cultura al País Valencià. Gandia, CEIC-Alfons el Vell. p.13-37. 2009.
BARONA VILAR, Josep Lluis.

Defining the 'children's problem' in Spain, 19001930: political initiatives and ideological debates. In: Andresen, Astri; Gronlie, Tore; Ryymin, Teemu (Ed.). Science, culture and politics: European perspectives on medicine, sickness and health. Bergen: Stein Rokkan Center for Social Studies. p.15-29. 2006.

BARONA VILAR, Josep Lluis; BERNABEUMESTRE, Josep.

La salud y el Estado: el movimiento sanitario internacional y la administración española (1951-1945). Valencia: PUV. 2008.

BARONA VILAR, Josep Lluis; BERNABEUMESTRE, Josep; PEDIGUERO GIL, Enrique. Health problems and public policies in rural Spain (1854-1936). In: Barona Vilar, Josep Lluis; 
Cherry, Steven (Ed.). Health and medicine in rural Europe (1850-1945). València, Seminari d'Estudis sobre la Ciència. p.63-82. 2005.

BERNABEU-MESTRE, Josep. La salut pública que no va poder ser: José Estellés Salarich (1896-1990): una aportació valenciana a la sanitat espanyola contemporània. València, Consell Valencià de Cultura. 2007.

BERNABEU-MESTRE, Josep, GALIANA-SÁNCHEZ, María Eugenia.

Salud comunitaria y acción social en el control epidemiológico del tracoma infantil, España (1932-1939). Asclepio, Madrid, v.63, n.2, p.507-520. 2011.

BORJA MARTÍN, Francisco.

Estación sanitaria del Puerto de Águilas. Anuario de la Dirección General de Sanidad. Madrid: Dirección General de Sanidad. p.75. 1924.

GALIANA-SÁNCHEZ, María Eugenia; BERNABEUMESTRE, Josep.

El problema sanitario de España: saneamiento y medio rural en los primeros decenios del siglo XX, Asclepio, Madrid, v.58, n.2, p.139-164. 2006.

GALIANA-SÁNCHEZ, María Eugenia; CREMADES, Angela; BERNABEU-MESTRE, Josep. Sanitary campaigns against trachoma in rural Spain. In: Andresen, Astri; Barona Vilar, Josep Lluis; Cherry, Steven (Ed.). Making a new countryside: health policies and practices in European History ca. 1860-1950. Bruxelles: Peter Lang. p.101-112. 2010.

GIMENO DE SANDE, Alfredo.

Memoria sobre la campaña nacional contra el tracoma: 1964-1965. Madrid: Dirección General de Sanidad. 1965.

HUERTAS, Rafael.

Política sanitaria: de la dictadura de Primo de Rivera a la Segunda República. Revista Española de Salud Pública, Madrid, v.74, p.35-43, 2000.

KONYAMA, Kazuichi.

History of trachoma control in Asia. Revue internationale du trachome et de pathologie oculaire tropicale et subtropicale et de santé publique, Annonay, v.81-82, p.107-168. 2004-2005.

LÓPEZ DE LETONA, Carlos.

La XIII Asamblea de la Sociedad Oftalmológica Hispano Americana (1923) y "el uso de los antojos" (1623). Archivos de la Sociedad Espanola de Oftalmologia, Madrid, v.81, n.1, p.49-50. 2006.

MARIOTTI, Silvio P.; PRÜSS, Annette.

The SAFE strategy: preventing tracoma: a guide for environmental sanitation and improved higiene. Geneva: World Health Organization. 2000 .
MARTÍNEZ ANTONIO, Francisco Javier; MOLERO MESA, Jorge.

Las campañas sanitarias como paradigma de la acción social de la medicina. Trabajo Social y Salud, Zaragoza, n.43, p.119-148. 2002.

MARTÍNEZ NAVARRO, Joan Ferran.

Lepra y salud pública en España. In: Comes Iglesia, Vicent Emmanuel (Dir.). Cuidados y consuelos: cien años de Fontilles. Generalitat Valenciana: València. p.51-89. 2009.

ORTIZ DE LANDAZURI, Antonio; LUENGO, Emilio.

Spain. In: International Health Year-Book 1924. Reports on the Public Health Progress of Twenty-Two Countries. Geneva: League of Nations Health Organisation. p.360-402, 1925.

PERDIGUERO GIL, Enrique (Comp.). Salvad al niño: Estudios sobre la protección a la infancia en la Europa mediterránea a comienzos del siglo XX. Valencia: Seminari d'Estudis sobre la Ciència, 2004.

RABADÁN FERNÁNDEZ, Pedro.

Factores epidemiológicos en la zona tracomatosa de la provincia de Alicante. Revista de Sanidad e Higiene Pública, Madrid, p.416-422. 1936.

RODRÍGUEZ OCAÑA, Esteban.

Salud pública y política agraria liberal en España: a Inspección de Sanidad del Campo (1910-1918). Asclepio, Madrid, v.62, n.2. p.327-352. 2010.

RODRÍGUEZ OCAÑA, Esteban.

La higiene infantil. In: Atenza Fernandez, Juan; Martínez Pérez, José (Ed.). El Centro Secundario de Higiene Rural de Talavera de la Reina y la sanidad española de su tiempo. Toledo: Junta de Comunidades de Castilla La Mancha. p.215-234. 2001.

RODRÍGUEZ OCAÑA, Esteban; MARTÍNEZ NAVARRO, Ferrán.

Salud Pública en España: de la Edad Media al siglo XXI. Granada: Escuela Andaluza de Salud Pública. 2008.

RODRÍGUEZ OCAÑA, Esteban; MENÉNDEZ NAVARRO, Alfredo.

Higiene contra la anemia de los mineros: la lucha contra la anquilostomiasis en España (18971936). Asclepio, Madrid, v.58, n.1, p.219-248. 2006.

RODRÍGUEZ OCAÑA, Esteban; MOLERO MESA, Jorge.

La cruzada por la salud. Las campañas sanitarias del primer tercio del siglo XX en la construcción de la cultura de la salud. In: Rodriguez Ocaña, Esteban. Salud pública en España: ciencia, profesión, política: siglos XVIII-XX. Granada: Universidad de Granada. p.235-256. 2005. 
RODRÍGUEZ OCAÑA, Esteban et al. La acción médico-social contra el paludismo en la España metropolitana y colonial del siglo XX. Madrid: Consejo Superior de Investigaciones Cientificas. 2003.

SOCÍAS, Arnaldo.

Epidemiología del tracoma. Tesis Doctoral Facultad de Medicina, Universidad Central, Madrid. 1940.

TAYLOR, Hugh R.

Trachoma: a blinding scourge from the bronze age to the twenty-first century. East Melbourne: Haddington. 2008.
VILA I CORO, Antoni.

Tracoma: aspecte mèdic i sanitari. Barcelona, s.n. 1933.

WRIGHT, Heathcote R.; TURNER, Angust; TAYLOR, Hugh R.

Trachoma. The Lancet, London, v.371, n.9628, p.1945-1954. 2008. 